\title{
AS CARACTERÍSTICAS DEFINIDORAS DO DUALISMO ALMA-CORPO NOS ESCRITOS DE PLATÃO
}

\author{
THOMAS M. ROBINSON* \\ Departments of Philosophy and Classics \\ University of Toronto
}

\begin{abstract}
RESUMO: As obras de Platão contêm a primeira explicação completamente articulada da relação entre alma e corpo na literatura ocidental. De um lado, Sócrates considera, de acordo com os órficos e pitagóricos, que a alma seja a sede do nosso eu real, e o corpo, o "túmulo" da alma. De outro lado, o mesmo Sócrates fala como se tanto corpo como alma pertencessem a uma terceira entidade que, seja o que for, seria o nosso eu genuíno. Após despender uma vida discutindo, em muitos diálogos (Fédão, Górgias, República, Timeu, Fedro), vários aspectos da relação almacorpo, Platão retorna ao tema, pela última vez, num passo das Leis. Ao fim, está lutando com o problema que jaz no seio de todo dualismo psicofisico, o de relacionar uma substância física com outra imaterial; ao fim, admite, abertamente, sua perplexidade.
\end{abstract}

PALAVRAS-CHAVE: relações entre alma e corpo; dualismo psicofísico; orfismo; pitagorismo; Platão.

As obras de Platão são únicas por vários resultados, não sendo o menor deles o fato de conterem a primeira explicação completamente articulada da relação entre alma (psyche) e corpo (soma) na literatura ocidental. O quadro que emerge não é desprovido de dificuldades, para não dizer contradições; assim, pode ser útil iniciar nosso exame com uma discussão breve e preparatória sobre o que sabemos das duas noções antes da época de Platão1.

É manifesto que, para os gregos antigos (tal como retratado, por exemplo, nas obras de Homero), o corpo consistia no eu "real" do indivíduo. Pode ser que seu princípio vital (literalmente, "vida", psyche) tenha sido considerado diferente do corpo e até sobreviver à morte deste, mas isso era um consolo pequeno; o que sobrevivia, o fazia num estado miserável e indesejável no Hades, não importan- 
do a virtude da vida do indivíduo sobre a terra. Pelo sexto século, com o advento do orfismo em certos setores do pensamento grego, a psyche começava a ser vista com mais direitos do que o corpo à denominação de eu real do indivíduo. Não somente se achava que sobrevivia ao corpo, julgava-se que, por seu meio, somos vivos, fisicamente e enquanto agentes racionais e, portanto, responsáveis (Heráclito, fr. 107, 118 DK). E seu estatuto ontológico era tal, que ela era o objeto potencial da recompensa ou punição eterna pela qualidade da vida vivida, sendo a existência corporal relegada ao estatuto de alguma forma de estação temporal ${ }^{2}$.

Embora o orfismo fosse considerado por muitos como a religião dos pobres e suas promessas de satisfação, posteriormente, uma espécie de ópio do povo proto-marxista, teve, em verdade, vários simpatizantes entre a intelligentsia, inclusive Píndaro, Empédocles e Sócrates. Parece claro, por exemplo, que Sócrates também pensava ter a alma mais fortes direitos do que o corpo à denominação de nosso eu real, tanto que parece ter defendido que nosso eu e nossa alma são o mesmo 3 . Como tal, a alma era, para Sócrates, evidentemente mais importante do que o corpo e, por isso, um objeto natural de muito maior cuidado do que o corpo. De fato, "o cuidado da alma" foi definido como o coração mesmo da filosofia de Sócrates (Burnet, 1916, p. 235s). Quanto a sua natureza, parece ter concordado com os órficos, pitagóricos, Heráclito e outros, que a alma é a sede de nosso eu racional e moral, bem como do biológico (Eutid. 295e4-5; Carm. 157a1-b1; Criton 47d3-4).

Sua opinião sobre a relação alma-corpo é algo obscura nos pormenores. Em uma passagem (Gorg. 493a1-5), ele diz, com visível aprovação, ter ouvido um filósofo dizer que o corpo é o "túmulo" da alma. Como propus alhures:

Segundo essa concepção, a alma, indubitavelmente, está destinada a ser o eu real, com o corpo servindo apenas como uma casca. É bem consistente enquanto doutrina, pois os desejos são atribuídos somente à alma; o corpo é tratado como, literalmente, peso morto (tethnamen) e evidentemente não toma nenhuma parte nas operações do indivíduo como tal (Robinson, 1970, p. 16).

Noutra passagem (Alc. 1 131a), fala do corpo como uma propriedade da alma. Contudo, não parece que esteja se referindo a propriedade aritmética, à maneira como um violinista possui um violino, mas a algo mais próximo a propriedade biológica, à maneira como um violinista possui uma mão que manipula 
o violino. Mas o argumento, tal como o possuímos, não é completamente claro ${ }^{4}$, e o Alcibíades 1 é, além disso, um diálogo apenas duvidosamente platônico. Felizmente, Sócrates volta à noção num diálogo que é sem dúvida platônico, o Cármides. E, aqui, ele talvez vá além do Alc. 1. Se posso citar uma explicação anterior:

No Cármides, 156 d e segs., temos uma discussão sobre a saúde, na qual Sócrates propõe concepções que alega ter aprendido de um médico que serviu ao rei trácio Zálmoxis. A passagem vale ser citada por inteiro: "este trácio disse-me que os médicos gregos, nessas suas noções que agora menciono, estão tão certos quanto podem; mas, ele acrescentou, nosso rei Zálmoxis, que é também um deus, diz mais: 'assim como não deves tentar curar os olhos sem a cabeça ou a cabeça sem o corpo, também não deves tentar curar o corpo sem a alma. E essa é a razão por que a cura de muitas doenças é desconhecida aos médicos da Hélade: eles desconsideram o todo, que deve ser estudado também, pois a parte nunca pode estar bem, a não ser que o todo o esteja'. Pois todo bem e todo mal, no corpo ou no homem todo, se origina, como ele declarou, na alma, e dela transbordam, como os olhos da cabeça. Portanto, se cabeça e corpo devem estar bem, deves começar curando a alma - eis o primeiro e essencial". O que concluir do conceito de alma, tal como parece emergir dessa passagem? Se a linguagem do médico trácio pretendeu alguma exatidão, a relação entre alma e corpo é, claramente, não de simples adição numérica, como se sua combinação fosse igual ao eu ou indivíduo completo. A chave para a relação (e para o próprio conceito de alma) parece estar na frase "porque eles desconsideram o todo". Esse "todo" poderia referir-se com sentido (a) ao corpo todo, ou (b) ao indivíduo todo, isto é, corpo e alma combinados.

Se (a) é o caso, os médicos gregos estão sendo corrigidos por menosprezarem os progressos na fisiologia geral; não conseguem compreender que indisposições de órgãos particulares só podem ser diagnosticadas adequadamente à luz de uma apreciação mais geral das operações do corpo humano como um todo. Contudo, dificilmente isso se ajusta às sentenças imediatamente anterior e seguinte, onde ocorre clara alusão a "alma". Assim, provavelmente (b) é a referência, e os médicos estão sendo repreendidos por não conseguirem perceber que muitas indisposições são, de fato (como diríamos hoje), psicossomáticas; poções e cataplasmas pouco farão 
para curar a dor de estômago que surge de um excessivo sentimento de culpa ou ansiedade, e o fisioterapeuta deveria saber quando, elegantemente, dar lugar ao psiquiatra.

Se isso é correto, é uma amostra de compreensão de medicina que antecipa muito das descobertas supostamente modernas no campo da psicologia, mas a noção de alma que parece requerer se mostra, no mínimo, notável em sua perspicácia. Pois se pretende, não apenas que a "alma" é o indivíduo todo, mas também que a relação entre alma e corpo é, evidentemente, aquela do todo à parte (ao que parece, no sentido específico do todo biológico à parte biológica, tal como a cabeça ao olho ou o corpo à cabeça) (Robinson, 1970, p. 4-5).

A relação é, de fato, de vinculação, e muito mais próxima a uma explicação monista da relação alma-corpo do que a uma dualista. E se a noção de corpo (vivo) não faz sentido a não ser na estrutura mais ampla da alma da qual é uma parte, à maneira como um olho vivo (enquanto distinto de uma peça de museu preservada) não faz sentido a não ser no contexto mais amplo da cabeça da qual ele é uma parte, parece seguir-se também a conclusão de que a "estrutura mais ampla” em questão deveria ser a primeira preocupação dos pesquisadores, com o risco de, de outro modo, colocarem o carro à frente dos bois. No caso da prática médica, a abordagem deve ser, como diríamos hoje, holística, sendo o holon ("todo") em questão a alma, de que o corpo compõe uma parte; ou, colocando nos exatos termos do próprio Sócrates, curar a alma, ele diz (157a1 e segs.), será preliminarmente indispensável a qualquer cura do corpo.

A idéia é, pelo que parece, única e notável; o tipo de monismo que parece apoiar inverte a descrição comum (na qual o corpo é a estrutura universalmente aceita a que a mente tem de estar de algum modo ajustada) e oferece-nos uma surpreendente alternativa, rica em possibilidades. Infelizmente, Sócrates (ou Platão) ou deixou de ver essas possibilidades, ou as rejeitou em favor daquelas que surgem de uma outra teoria, mais manifestamente dualista. A não ser por uma possível analogia no plano cosmológico, no Timeu ${ }^{5}$, a noção certamente nunca retorna nos diálogos.

Não sabemos se qualquer das opiniões acima foi do Sócrates histórico. Assim, o fato de Platão atribuir todas as três, em diferentes momentos, a Sócrates, sugere que o próprio Sócrates teve alguma dificuldade para atacar o problema, oferecendo várias soluções tentativas em diferentes momentos em suas discus- 
sões - desde o dualismo (aritmético) mais puro do Górgias 493a1-5 ao dualismo mitigado do Alcibíades 1 (se for um diálogo platônico genuíno) e ao monismo apenas formulado do Cármides. Das três, contudo, provavelmente a primeira foi a dominante, se a evidência do mito do Górgias deve ser considerada uma evidência firme das concepções do próprio Sócrates ${ }^{6}$. Aqui, a alma no pós-vida é, de fato, um "contra-indivíduo" que desfruta de todas as outras características do indivíduo nesta vida, exceto da materialidade. Como tal, é a alma-eu completamente autônoma do Protágoras, uma alma que pode, periodicamente no espaçotempo, "possuir" um corpo físico, mas para a qual um corpo físico não é mais uma sua parte do que um violino é "parte" de um violinista. É também, parece, ela própria viva, assim como é um princípio de vida, e a vida que possui pode talvez ter sido também considerada por Sócrates - novamente segundo um modelo órfico de pensamento - muito duradoura, ou mesmo eterna?

A palavra "talvez" precisa ser salientada aqui, porque o Sócrates da Apologia se confessa um agnóstico em matéria de pós-vida. Se é o Sócrates genuíno quem fala, referências em outros diálogos a uma pós-vida podem dizer respeito a um aspecto do orfismo aceito sem dúvida mais por Platão do que pelo próprio Sócrates. Por outro lado, nada há de intrinsecamente improvável no fato de o próprio Sócrates ter hesitado sobre o assunto, expressando diferentes opiniões em diferentes momentos; e, nisso, não teria sido o último grande filósofo a fazê-lo.

Quanto ao bem-estar ou qualquer outro estado do corpo e da alma, cada um, diz ele no Górgias, pode ser caracterizado como saúde autêntica, pseudosaúde ou doença, sendo necessário um bom médico para curar a pseudo-saúde ou a doença do corpo, um bom juiz ou legislador para curar a pseudo-saúde ou doença da alma. O termo que utilisa para os que executam esta última tarefa psychiatroi ("os que curam a psyche") - é um neologismo surpreendente e, é claro, foi revivificado em nosso século. Quanto ao que constitui a doença específica da alma, diz ser o vício, cuja cura será produzida reprimindo os desejos insalubres $d a$ alma, à maneira como um corpo doente é curado pelo controle de seus desejos insalubres. Algumas vezes, diz ele, isso pode envolver medidas drásticas, tais como cauterização ou cirurgia; e cauterização ou cirurgia, para a alma, compreendem as mais pesadas punições da lei.

Creio haver vários aspectos interessantes sobre essa idéia. $O$ primeiro é sua clara assunção de um paralelismo entre alma e corpo na estrutura e nas atividades, que prima facie se opõe à assimetria evidentemente presente em qualquer teoria de que somente a alma é o indivíduo real. O segundo é sua evidente 
assunção de que alma e corpo se caracterizam por "desejos" de vários tipos, tanto que se poderia denominá-la uma versão anterior da teoria do "indivíduo-duplo" (em contraste com a teoria do "indivíduo como um instrumento"). O terceiro é a assunção, também comum à teoria "indivíduo como um instrumento", de que a alma é a sede de nossa atividade moral, social e política. E o quarto é a idéia de que a "repressão" de certos desejos da alma é uma terapia importante.

O Górgias é, na aceitação comum dos estudiosos, um diálogo escrito muito próximo ao final do período "socrático" de Platão, e é possível que sejam suas muitas das idéias acima, ou, se não, de qualquer forma, prenúncios delas. Seja como for, no Fédão, escrito pouco depois do Górgias e no início do assim chamado período metafísico de Platão, vemos o que considero o primeiro exemplo claro do próprio Platão abordando a herança socrática sobre o tema da alma e corpo. A cena é a cela da morte de Sócrates, durante as últimas horas antes que ele beba a cicuta. Símias e Cebes, os principais interlocutores de Sócrates, estão espantados com sua disposição em face da morte, e igualmente espantados com o motivo para tal disposição: sua convicção de que seu eu real - sua alma - sobreviverá à sua morte corporal e subsistirá no estado de felicidade que é a recompensa por uma vida virtuosa. Questionado, Sócrates esclarece que seu orfismo, se é que se trata disso, envolve tanto razão como simples fé, e uma série toda de argumentos é exposta para demonstrar, até onde lhe parece possível, que a alma que sobrevive é de fato imortal. Enquanto tais, os argumentos, embora fascinantes, podem aqui ser deixados de lado. Mais importantes são as muitas noções de alma que emergem do diálogo e alguns dos problemas que geram.

Observações anteriores de Sócrates sugerem que ele vê a alma como algum tipo de "indivíduo interno" distinto do corpo e que reage a ele de vários modos. Assim, diz-se que a sensação corporal "abala" a alma, que faria tudo para "evitá-la", "dar adeus" a ela e "ficar sozinha e por conta própria". O abalo causado pelo corpo aparece copiosamente na esfera cognitiva e moral. Entre os males do corpo que Sócrates enumera estão, por exemplo, sua "insensatez" e "estupidez", que deve ser combatida por uma alma que ele claramente considera, entre outras coisas, como um princípio de cognição (chega ao ponto de chamá-la "inteligência”, num contexto em que a própria palavra alma teria sido uma expressão perfeitamente apropriada). Mostra-se claro que o corpo é também uma fonte potencial de dano moral, quando afirma que este, com sua presença, "contamina" a alma, "preenche-a com suas luxúrias" e "enfeitiça-a com suas paixões e prazeres". 
Algumas destas idéias, é claro, alinham-se bem mais com o que surgiu em diálogos anteriores: alma e corpo são substâncias distintas, a alma é o eu real do indivíduo, é nossa fonte de atividade cognitiva e moral. Ganhando ênfase um pouco maior, há a idéia do corpo como causa ativa de dano no nexo alma-corpo. Certamente não é mais uma "propriedade" no sentido neutro em que se diz sê-lo um instrumento, mas sim algo mais similar a um contra-indivíduo, com seus próprios prazeres, dores e desejos particulares, todos, no melhor dos casos, um transtorno para a alma e, no pior, algo apto a causar dano significativo. A certa altura, é considerado, sumária e claramente, "mau".

Esta é, de fato, uma versão muito mais forte daquilo que anteriormente, na discussão do Górgias, fora chamado teoria do "indivíduo-duplo" do indivíduo. O que a torna mais forte? $O$ primeiro ponto é sua ênfase na alma como um agente cognitivo tanto quanto moral, embora, dado o tom em geral intelectualista da teoria moral de Sócrates, talvez não se deva valorizá-lo demais. O segundo, e mais importante, é o sentido de total estado de guerra entre alma e corpo, e entre os interesses de alma e corpo; não são mais considerados apenas como curiosamente análogos em suas estruturas e atividades. A guerra, acrescenta-se, é vista, literalmente, como guerra até a morte; a alma somente obterá sua vida autêntica quando finalmente separada do corpo. Enquanto isso, o indivíduo verdadeiramente bom e justo fará o máximo possível para viver como se não possuísse corpo algum.

Tal concepção da relação corpo-alma, algo desanimadora, mas historicamente bastante influente, é a que a maioria extrai de uma primeira leitura do Fédão, e é verdade que, realmente, é a concepção dominante no diálogo. Contudo, ela é paralela a outras versões, de vários modos conflitantes, da relação corpo-alma, que Platão por enquanto parece disposto a deixar irreconciliadas. Num momento da discussão, por exemplo, ele cita, com evidente aprovação, a doutrina órfica do corpo como uma prisão para a alma (82e2 e segs.), noção análoga àquela anterior, do corpo como uma simples propriedade física, embora, agora, com maior ênfase sobre seu poder de confinamento. Noutro lugar, fala da alma de maneiras que sugerem alguma espécie de fluido ectoplásmico penetrante e coextensivo com o corpo, uma entidade que, se suficientemente "contaminada" e "infectada" pelo corpo, pode mais tarde retornar à terra como o que a maioria chama um fantasma. E noutro lugar ainda (especificamente, no primeiro e último argumento em favor da imortalidade), refere-se à alma estritamente nos termos de um princípio vital ou suporte vital; para os propósitos dos argumentos em questão, suas eventuais características "pessoais" são ignoradas. 
Como Dodds disse uma vez, "a época clássica herdou uma série completa de retratos inconsistentes da alma ou eu" (Doods, 1951, p. 179), e parece que muitos deles encontraram seu lugar no Fédão. 1) Por um lado, é forte a argumentação de que a alma é completamente imaterial e, daí, semelhante às Formas transcendentes; por outro lado, sua descrição em termos ectoplásmicos parece ser transportada de um período anterior em que era concebida em termos mais francamente físicos. 2) Por um lado, é forte a argumentação de que é estritamente uma unidade, sem partes e imune à mudança e, daí, novamente semelhante às Formas transcendentes; por outro lado, é vista como nosso eu mais genuíno, completa, com toda a complexidade e mudança advindas do conhecimento, desejo, arbítrio e toda uma classe de sofrimentos e desejos possíveis. 3) Por um lado, é considerada duplicada, de modo não-natural, para uma existência terrena com um corpo que é, a maior parte do tempo, inimigo de sua verdadeira felicidade e interesses, que se encontram em uma existência em outra parte, desencarnada e imaterial; por outro lado, enquanto princípio vital, parece ter como sua essência mesma animar o que é físico. 4) Por um lado, diz-se que a alma e o eu são o mesmo; por outro lado, Sócrates fala, às vezes, e talvez em sentido lato, como se corpo $e$ alma fossem as propriedades de uma terceira entidade que - seja o que for - seria o eu genuíno.

À primeira vista, essas variadas noções de alma não são fáceis de harmonizar, mas o problema de harmonizá-las - se Platão viu como um problema - era, para ele, claramente menos importante do que os pontos principais que se empenhava por reforçar, resumidos a seguir. A alma é, por sua natureza, de maior importância do que o corpo no nexo corpo-alma; há uma necessidade dominante de cuidar de nosso eu genuíno, a alma, acima de nosso suposto eu, o corpo; a mesma alma que é princípio/suporte vital é também, ela própria, viva, um indivíduo que consiste no eu genuíno e dotado de faculdades cognitivas e sensibilidade moral; a felicidade da alma não se encontra em nada proporcionado pelo mundo do espaço-tempo, mas na contemplação eterna das Formas transcendentes.

A conclusão de tudo isso é que, para o Sócrates do Fédão, a relação almacorpo é essencialmente não-natural. Encontra evidência para tanto no que lhe parece a divergência e, em muitos exemplos, um completo conflito entre desejos "corporais" (por comida, bebida e sexo) e os desejos da alma (por conhecimento e bondade), e entre dores e prazeres "corporais" (ligados aos desejos corporais acima) e as dores e prazeres da alma (ligados aos desejos da alma acima). Não há conflito na alma enquanto tal, porque a alma é uma substância simples; o conflito "interno" é, invariavelmente, entre corpo e alma. 
Ao escrever dessa maneira, Platão está no limite extremo do dualismo psicológico; em nenhum outro diálogo ele se expressa em termos tão rígidos e firmes a respeito da relação entre corpo e alma. Até que ponto, no momento em que escreve o diálogo, ele próprio acreditou que esse dualismo acentuado seria uma descrição autêntica dos fatos, ou até que ponto tal dualismo serviu ao propósito dramático de explicar a disposição de Sócrates em face da morte, nunca saberemos. Mas uma coisa sabemos. No diálogo ao que tudo indica imediatamente posterior ao Fédão, isto é, na República, ele já passou para uma descrição muito mais sofisticada da relação alma-corpo. E é para esse diálogo que nos voltamos agora.

$\mathrm{Na}$ República, muitos dos sentidos de alma que surgiram no Fédão retornam, mas há uma sua descrição bastante original, em que é dividida em três partes, razão, "animosidade" e desejo visceral. Com essa mudança, Platão refinou aquela bi-partição da alma em razão e impulso visceral que (com a exceção de um argumento no Fédão, baseado na assunção de sua unidade e indivisibilidade) caracterizou seu pensamento anterior. Se, no entanto, ele progrediu ou regrediu ao tentar separar nosso impulso não-racional em "animosidade" e desejo visceral, isso tem dividido e provavelmente continuará a dividir os leitores do diálogo. Para muitos, a "animosidade" a que se refere não se distingue claramente de outros desejos não-racionais, a despeito de suas tentativas de argumentar em contrário; e não é difícil argumentar que ela é, de fato, inventada como o correlato (implausível) de um item no notório (e muito mais defensável) análogo político da alma descrito pormenorizadamente na República, isto é, no estado tripartite. Seja como for, a tripartição da alma, correta ou erroneamente, chegou a ser considerada por muitos como uma das doutrinas nucleares do platonismo, e devemos dedicar algum tempo a seu exame (cf. supra).

Um aspecto imediatamente notável da teoria é o modo como todas as três partes da alma são descritas em termos semi-autônomos; cada uma tem seus próprios desejos, prazeres e sofrimentos, freqüentemente descritos em pormenores tão "pessoais" que às vezes tem-se a impressão de tratar-se de uma teoria de três indivíduos internos, não de três partes de uma substância. Contudo, se este modo de falar, assim como aquele anterior sobre uma diferença evidente entre corpo e alma, não deve ser entendido literalmente, surge o ponto crucial: as tensões que todos sentimos não são, afinal, como o Fédão poderia ter-nos levado a supor, tensões entre alma e corpo, mas tensões no interior da própria alma (ponto, por coincidência, esboçado no Górgias 493a1-5, a que Platão agora retorna).

Junto a essa reafirmação da doutrina anterior sobre a natureza de nossas tensões (afirmação originariamente expressa em termos de bipartição e não 
tripartição da alma, mas ainda a mesma afirmação), surge uma evidente reavaliação das partes da alma quanto ao papel que cada uma desempenha. Enquanto, por um lado, Platão está ainda, no início do diálogo (antes que a nova teoria da tripartição tenha sido de fato mencionada), predisposto a dizer que "na alma de um indivíduo, um elemento é melhor, outro é pior" (431a4-5), no livro 9, quando sua psicologia tripartite já foi completamente articulada, todas as três partes da alma são agora reconhecidas como possuidoras de um papel necessário e vantajoso no bom funcionamento do todo (586e4-587a1).

Um aspecto final e crítico de sua psicologia reavaliada - coincidemente também prenunciado no Górgias - é o evidente abandono da teoria do Fédão a respeito do que constitui a saúde da alma e do corpo. Pois a saúde, vista como uma metáfora básica para a justiça, é agora cuidadosamente descrita, nos moldes da medicina grega contemporânea, como uma harmonia de itens no organismo, seja este o corpo ou a alma. Falando nos termos escrupulosamente funcionalistas e teleológicos elaborados no final do livro 1, Sócrates descreve como o correto funcionamento (=saúde) do corpo envolve o correto funcionamento de cada uma das partes que o compõem; em sua própria terminologia, cada parte executa a função que lhe foi destinada. De modo semelhante, na alma justa (=saudável), a saúde/justiça consiste em cada uma das três partes da alma executar a função que lhe foi destinada.

Se a parte racional da alma é ainda, para Platão, de longe a mais importante, e talvez a única a ser imaterial e imortal (cf. infra), o papel necessário das outras duas partes ici bas levou Platão a um passo gigantesco para além das opiniões anteriormente propostas no Fédão. Agora, o corpo não é mais visto como alguma forma de contra-indivíduo material, completo, com desejos próprios, em oposição ao indivíduo imaterial que é a alma. Todos os desejos são, realmente, diz Platão, uma característica da alma; ainda que muitos deles se descrevam corretamente operando via corpo. E todos estes, se corretamente canalizados, podem ser comandados de modo a servirem aos fins de nossos eus racionais e, em última instância, mais genuínos.

Tal canalização, afinal, é algo muito próximo ao que Platão entende por educação. Esta, como era de esperar, compreende qualquer técnica que pareça necessária para produzir e manter harmonia entre os itens incluídos no corpo, harmonia entre as partes incluídas na alma e harmonia - não conflito - entre alma e corpo. Parece que Platão se distanciou da posição do Fédão o máximo possível, embora ainda se considere um dualista psicofísico. 
Embora esse modo de falar seja correto em sentido lato, permanece tal com relação a um único aspecto, ainda que crítico, da teoria alma-corpo de Platão como um todo. Outras características da teoria não sofreram mudanças notáveis. Alma e corpo continuam a ser considerados realmente distintos, não apenas logicamente. Sua suposta "adição" ainda faria dois. Ao fim e ao cabo, um permanece sendo mais importante do que o outro, a despeito da reavaliação dos impulsos associados à condição corporal; mesmo a educação física é afirmada em vista do bem-estar do corpo apenas casualmente, mas principalmente - em conjunção com a mousike - em vista do bem-estar da alma (Rep. 411e-412a). E em mais outro esforço para provar a imortalidade da alma (608c e segs.), em que por tudo que foi dito no Fédão - se poderia esperar uma afirmação clara de que somente a alma enquanto razão é de fato imortal, a discussão é estranhamente obscura; talvez ainda relutante em descartar a concepção órfica da alma como um indivíduo completo no além-vida e não apenas um intelecto desencarnado, Platão apresenta um argumento de uma ambigüidade talvez proposital, onde se mostrou bastante difícil saber se ele crê que o que sobrevive como uma unidade é simplesmente a alma enquanto razão, ou se crê que é alguma entidade unificada que contém em si, de algum modo imaterial, tudo o que constituiu o que fora um dia a alma tripartite ${ }^{8}$. Numa palavra, a despeito dos progressos evidentes, na República, da concepção platônica de alma, muitas facetas do problema de sua natureza, constituição e relação com o corpo ainda permanecem, ao fim do diálogo, num estado de ambigüidade (talvez intencional).

Mas ambigüidade não é dúvida radical, e, no Timeu, que agora julgo ser um diálogo escrito perto do início do último período dos escritos de Platão (Robinson, no prelo), ele retorna extensamente ao tema da alma, argumentando com minúcia que todas as coisas vivas são, por definição, animadas, e, visto que o universo é algo vivo, também deve ser animado. Esta última hipótese é intrigante e só pode ser discutida aqui de passagem. Quanto à alma humana, mais uma vez é dita tripartite e, mais uma vez, claramente, a julgar pela profusão de metáforas políticas diretamente extraídas da discussão da República, em referência à mesma analogia política desse diálogo. E novamente as três partes são localizadas, respectivamente, na cabeça, tórax e ventre.

Mas há algumas diferenças dignas de nota. Agora não há dúvida quanto à parte da alma que sobrevive e é imortal: a razão somente. E a composição da razão, seja daquela Razão que constitui a totalidade da alma do mundo, seja da parte raciocinante da alma humana, é descrita agora como, nalguma medida, material. À primeira vista, mudança paradoxal, em vista do interesse anterior de 
Platão, no Fédão e na República, por acentuar a total imaterialidade da alma (racional). Mas, na verdade, tal mudança se confronta com um aspecto fundamentalmente problemático de qualquer teoria do chamado dualismo psicofísico "ingênuo", a saber, a suposição de que uma substância física e outra totalmente não-física se relacionem e combinem. Se se puder mostrar que a alma é em algum sentido imaterial e em algum sentido material, provavelmente se terá contribuído para minimizar o problema. Ou, seja como for, podemos especular assim; o próprio Platão não enfrenta o problema exatamente nestes termos, mas sim nos termos de sua metafísica e epistemologia básicas. O resultado, no entanto, é o mesmo; até nossa alma imortal, racional, é agora pensada como material em certo sentido, e, conseqüentemente, sua vida imortal é descrita, não como uma existência imaterial eterna entre as Formas, mas como uma perpétua existência material da animação, no espaço e no tempo, das estrelas e planetas.

Propositalmente ou não, Platão parece ter, aqui, conciliado duas concepções claramente divergentes de alma, uma, material, a outra, imaterial, que surgiram primeiro no Fédão, de modo a dar crédito a ambas. Modelada deliberadamente pelo Demiurgo para que possua a) um tipo "intermediário" de realidade entre a realidade absoluta das Formas transcendentes e a semi-realidade dos objetos no espaço-tempo, e b) versões "intermediárias" daquelas características de Identidade e Diferença que nos permitem propor juízos epistemológicos básicos, a alma (racional) mostra agora, por sua estrutura mesma, possuir uma afinidade natural por ambos os universos de Platão e uma habilidade, em circunstâncias muito favoráveis, para obter uma compreensão máxima de cada um. No caso do mundo das Formas, essa compreensão se dará no plano do conhecimento; no caso do mundo do espaço-tempo, no plano da opinião verdadeira.

Junto com essa notável clarificação do estatuto "anfíbio" da alma (um estado implícito nos relatos órficos da transmigração, mas agora defendido pela primeira vez por Platão como uma crença - assim como a crença na imortalidade - que é sustentável por argumento explicitamente filosófico), surge um esforço, igualmente notável e pouco notado, por conferir sentido pleno ao fato da animação enquanto tal, seja humana, animal ou vegetal. Ignorando (se é que não rejeita explicitamente) a explicação órfica oficial da animação como resultado de uma "queda" coletiva, de um pecado individual, ou de ambos, e retomando a idéia, esboçada inicialmente no Mito de $\operatorname{Er}(\operatorname{Rep.} 10)$, de que nós somos responsáveis pela vida em que nascemos - "não se deve culpar Deus" -, Platão argumenta que, no início, o Demiurgo criou todas as almas iguais. Embora haja alguma dúvida a respeito do seu argumento no pormenor ${ }^{9}$, ele parece dizer que a primei- 
ra geração de humanos criada pelo Demiurgo e seus ajudantes divinos foi toda de homens. Conforme morriam e eram devidamente reencarnados, aqueles que haviam vivido uma vida "covarde" e, em termos mais gerais, moralmente insatisfatória ${ }^{10}$, eram reencarnados como mulheres (!); os que viveram em níveis variados de estupidez eram reencarnados como tipos diversos de pássaros ou animais.

Se o dito acima significa o que parece significar, as investigações de Platão sobre a natureza da alma e do corpo conduziram-no a uma descrição da totalidade do mundo natural como diferentes casos, em suas espécies variadas (entre os humanos, ao que parece, incluindo a espécie inteira das mulheres), do que se poderia chamar "degradação apropriada" para o alojamento das almas dos homens que sofrem punições de alguma das formas descritas acima. Bizarra e infeliz inflexão da teoria da transmigração, para a qual fui incapaz de encontrar uma fonte segura, órfica, pitagórica, zoroastriana ou hindu, e, por isso, faute de mieux, atribuo-a, tentativamente, ao próprio Platão, ou, talvez, ao pitagórico renegado Filolau, em cujas obras (perdidas) há razão para crer que boa parte do Timeu se baseou.

O que começou como uma decidida afirmação da eqüidade do Demiurgo para com todos os humanos levou Platão a um terreno muito estranho, cujos problemas extraídos ele pode ter chegado a ver talvez como maiores do que os que pensava estar solucionando. Se um certo leão Seregenti é a reencarnação de um certo guerreiro Masai, possui ele tanto a alma do leão como a alma do guerreiro, somente a alma do leão, ou somente a alma do guerreiro? Todas as respostas à questão criam problemas para quem acredita, como deve fazê-lo um partidário da doutrina da transmigração, que uma vida "boa" como a de um leão (o que quer que isso possa significar...) assegura um passo acima na escala de vidas - talvez ao nível das mulheres... -, ou que uma vida "má" como a de um leão assegura um passo abaixo, talvez ao nível de um esquilo ou caracol.

Quanto à concepção completa de "degradação apropriada", no caso das mulheres, parece referir-se a características do corpo e da alma; elas são, diz Platão noutra passagem do diálogo, menos fortes fisicamente ${ }^{11}$ do que os homens, e na passagem subseqüente, bem como noutras do diálogo, assevera, como vimos, que elas se inclinam, na alma, a um comportamento moralmente inaceitável, especialmente à covardia. A conclusão, aqui, tão infeliz como as extraídas acima, parece ser que Platão - adotando uma posição inequívoca numa controvérsia que ainda é nossa - julga haver uma diferença "natural" entre almas humanas de homens e mulheres análoga à diferença de vigor corporal, diferença 
que tem a ver com a superioridade moral natural do homem. Preservando a doutrina socrática primitiva de que o pior que se pode fazer a alguém é torná-lo moralmente pior como pessoa, Platão agora chegou próximo a um argumento (mas que argumento!) que mostra que a punição adequada para a alma de um homem que demonstrou defeito moral é correr o risco - por associação - de degradação moral ainda maior, ao ser encarnado no corpo de uma criatura de valor moral intrinsecamente menor do que o seu, isto é, no corpo de uma mulher...

Seria fácil, mas talvez fácil demais, descartar o dito acima como puramente "mítico", nada que alguém tão sofisticado como Platão pudesse ter endossado. Pois, num diálogo posterior, as Leis (944d8-e2), após mencionar como Ceneu de Tessália fora um dia mulher, mas foi transformado por um deus em um homem, afirma que, "se fosse possível o processo inverso, a transformação do homem em mulher, isso de certo modo seria a mais adequada das punições para o homem que lançou fora seu escudo". Esteja ele ou não, com tal afirmação, sugerindo um afastamento da doutrina da metempsicose e, particularmente, da singular doutrina encontrada no Timeu, suas impressões sobre as mulheres como criaturas de degradação moral, apropriadas para servir como prisões para homens covardes que sofrem punições, claramente não sofreram nenhuma mudança ${ }^{12}$.

Mas seria impróprio deixar o Timeu num tom tão desanimador, visto que nele ocorrem também algumas afirmações de sagacidade notável sobre doenças psicossomáticas. Após uma breve discussão sobre indisposições corporais, Timeu prossegue:

Tal é o modo como surgem doenças do corpo; já doenças da alma causadas pela condição corporal surgem da seguinte maneira. Admitamos que a insensatez é doença da alma; e há duas espécies dela, loucura e estupidez. Conseqüentemente, qualquer afecção que as cause deve ser considerada uma doença; e entre as doenças mais graves para a alma devemos classificar os prazeres e sofrimentos excessivos... Pois ele é, a maior parte de sua vida, enlouquecido por esses prazeres e sofrimentos intensos; e quando sua alma, por causa do corpo, torna-se doente e insensível, geralmente se considera que ele não está doente, mas sim que é deliberadamente mau... O certo é que a intemperança sexual é uma doença da alma que surge, em grande medida, por causa de uma única substância (a medula, TMR), que, devido à porosidade dos ossos, irriga o corpo com seus humores. Poderíamos praticamente dizer, em verdade, de tudo que se denomina incontinência no prazer, que sua censura 
é injusta, como se os homens fossem intencionalmente maus. Ninguém é intencionalmente mau; o homem mau torna-se tal devido a algum hábito defeituoso de corpo e uma formação inculta, e essas são atribulaçôes indesejadas que ocorrem em qualquer homem contra sua vontade. Novamente, quanto aos sofrimentos, a alma também recebe muita maldade do corpo. Quando fleumas ácidos e fortes ou humores biliosos percorrem o corpo e, não encontrando saída, ficam presos e desordenados com a mistura dos vapores que deles surgem com o movimento da alma, eles provocam todo tipo de doenças da alma, de maior ou menor intensidade e extensão. Avançando pelas três sedes da alma, conforme a região que invadem respectivamente, eles produzem diversos tipos de indisposições e desanimos, de precipitações e covardia, frouxidão e esquecimento.

Então, após uma breve discussão sobre má educação familiar e política, conclui:

Eis como todos nós que somos maus nos tornamos tais, por meio de duas causas que são completamente contrárias à vontade. Nisso, a censura deve recair mais sobre os pais do que sobre os filhos, mais sobre os que dão educação, do que sobre os que a recebem. Mas um homem deve empreender seus esforços máximos, por meio da educação, ocupações e estudo, para escapar da maldade e agarrar-se a seu contrário.

Eis aí um notável pequeno ensaio sobre (para inventar uma expressão) doença sômato-psíquica (distinta de doença psicossomática) - o primeiro do gênero na literatura ocidental - e sobre a relação entre tal doença e responsabilidade moral contínua. A despeito de suas intuições e importância, distingue-se por ser muito pouco lido, inclusive pelos que afirmam conhecer um pouco Platão. E vem nos seus calcanhares uma breve descrição da doença psicossomática da qual uma parte (de muito interesse aos que se ocupam com a educação!), mais uma vez, merece citação:

Quando a alma é forte demais para o corpo e de temperamento ardente, desarranja toda a sua estrutura e o preenche com suas indisposições internas; ela o consome quando se lança ao estudo e investigação; no ensino e na controvérsia, pública ou privada, ela se inflama, estende seu tecido por todas as disputas e controvérsias que surgem e, ocasionando fluxos, ilude a maioria dos assim chamados médicos, responsabilizando a parte inocente. 
Pode-se medir exatamente até onde chega Platão com clareza nessas questões por uma breve retomada do Górgias, onde, como vimos, alma e corpo são considerados entidades estritamente paralelas, cada uma com seus estados de saúde e doença definidos adequada e meticulosamente, cada uma curável de uma maneira apropriada a sua espécie de doença, psíquica ou somática; se ele tinha, nessa época, opiniões sobre um suposto contato entre ambas, é evidente seu silêncio a esse respeito.

Não que alma e corpo, é claro, não continuem a operar, para Platão, como substâncias paralelas, junto com a afirmação concomitante de que um dos dois é intrinsecamente mais importante do que o outro (89d4-7). Concluindo sua discussão sobre doença psicossomática e sômato-psíquica, por exemplo, ele observa que o melhor medicamento preventivo consiste em movimento físico ou exercício para o corpo e exercício não-físico (=contemplação) para a alma. É uma doutrina da mens sana in corpore sano e, como muito nessas passagens finais do Timeu, tornou-se familiar a ponto de parecer simples truísmo. Mas, em sua época, tal idéia era uma revolução.

As opiniões de Platão parecem ter mudado com os anos também sob outro aspecto crítico, e isso com relação à própria definição de alma. No Fedro, um diálogo escrito, creio eu, não muito depois do Timeu, Platão se aproxima de uma definição nova e singular de alma (racional) como "movimento automovente"(245c-246a). E, com esta definição - por mais lacônica e opaca que possa parecer -, após uma vida de escritos sobre o tema geral, finalmente ele se defronta com a questão que um amigo muito cético deve ter posto, a saber, por que "alma" é necessário para explicar uma coisa viva qualquer, humana ou não. Os atomistas não poderiam, o tempo todo, estar certos, e as conjunções transitórias de partículas de matéria que se movem ao acaso no espaço seriam tudo que existe? Em sua resposta, formulada cuidadosamente, Platão reitera sua concepção de conexão causal entre movimento e vida, distinguindo-se algo vivo de algo sem vida por seu poder de "automovimento"(num sentido fraco da expressão). Nisso, todos os gregos, mesmo que ingênuos, concordariam com ele. $\mathrm{O}$ argumento seguinte, no entanto, com poucas exceções, teria deixado todos eles para trás, pois então ele argumenta que há uma causa ou gatilho para esse automovimento (nomeado enganosamente) e que essa causa ou gatilho é o automovimento autêntico da alma (raciona).

Como tal automovimento autêntico é, para Platão, evidentemente sem início no tempo, ele continua então a argumentar que a alma racional é tanto imortal como - talvez mais significativamente em vista de suas implicações para 
a ação - eterna. Pois, até agora, Platão argumentou que a alma tinha um início temporal - em verdade, que o instante de sua formação no tempo pelo Demiurgo era o primeiro instante do tempo. Nessa estrutura geral a alma era considerada a criação e a serva de um deus ou deuses que serviriam como árbitros de suas ações. Com a nova definição, todo o quadro é posto em questão num só golpe, pois, ao que parece, a alma racional é uma entidade incriada e tão eterna quanto os próprios deuses.

Contudo, em Platão, muito freqüentemente, uma idéia nova e instigante surge associada a outra, relativamente conservadora, apenas compatível, quando o é, à primeira. Em lugar do exame esperado das implicações potencialmente explosivas para a ação da definição formulada de um modo novo, Platão nos oferece uma descrição mítica famosa da alma nos termos de um condutor e dois cavalos que, em grande medida, é uma repetição da teoria da alma-tripartite da República e do Timeu ${ }^{13}$. E no mesmo contexto descreve a reencarnação nos termos tradicionais de uma queda, embora, agora, o além-mundo seja de fato seu próprio mundo das Formas; e a própria alma encarnada é descrita como uma ostra em uma concha, quase da mesma forma que, antes, no Fédão, a descrevia como aprisionada (Fedr. 250c6; Féd. 82e3). Quanto à conduta, não há sugestão de que a nova definição de alma racional tenha modificado a posição básica de Platão sobre o tema; nosso interesse principal, nossa obrigação primeira, num mundo em que nos dizem, confusamente, que "toda alma cuida de tudo que é inanimado"(246b6) e que Zeus "ordena e cuida de tudo"(246e5-6), permanece cuidar por uma alma moralmente sadia (=equilibrada), uma alma que, em seu aspecto racional, é afinal nosso eu real. Mesmo sobre este último ponto Platão nos deixa num estado de ambigüidade, já familiar. Pois a alma desencarnada do mito do Fedro mostra-se quase idêntica à alma descrita em tantos outros mitos escatológicos de Platão, uma alma cujas características todas parecem sobreviver, e não apenas sua razão. E, como em diálogos anteriores, Platão não insinua nenhuma intenção de esclarecer a situação ou se, na verdade, considera desejável um esclarecimento. Para tanto, temos de esperar até o décimo livro do que bem pode ter sido sua última obra, as Leis.

Aqui, ele reafirma sua tese, exposta inicialmente no Fedro, de que a fonte de todo movimento é a alma automovente eterna, mas, desta vez, a afirmação foi ampliada de modo a incluir toda a alma, não apenas - como parecia concluir no contexto o argumento do Fedro - a alma racional. Enfatiza-se também que o "movimento" em questão não é simplesmente o movimento físico associado à vida orgânica; os "movimentos" da alma são agora, pela primeira vez, sistemati- 
camente arrolados como "desejo, reflexão, previdência, deliberação, julgamento, verdadeiro ou falso, prazer, dor, esperança, temor, ódio, amor e qualquer movimento análogo ou primário possível" (897a1-4).

Uma ambigüidade, no Fedro, quanto ao estatuto ontológico da alma, foi decisivamente resolvida. Ali, lembre-se, Platão escrevia sobre a alma e Zeus de um modo que sugeria que ambos eram entidades eternas independentes, nãocontingentes que e ambos claramente executavam uma função "protetora" de idêntico alcance no esquema total das coisas. Esclarece-se agora que a alma, embora automovente e eterna, o é numa situação de eterna dependência, quanto a sua gênese eterna, de um princípio divino transcendente. $\mathrm{O}$ que à primeira vista parecia ser o estatuto eternamente não-contingente da alma (racional) revelou-se agora estatuto eternamente contingente de toda a alma. Mas, ainda aqui, ao fim, Platão permanece insistentemente enigmático. Se, como ao menos parece possível, supõe-se que o próprio princípio divino transcendente é uma alma, a universalidade de sua afirmação da contingência, por sua vez, é claramente posta em questão.

Isso nos leva a regiões da metafísica platônica que teriam de ser discutidas noutro lugar; mas se disse o suficiente para estabelecer que, afinal, Platão é um desbravador do campo da psicologia filosófica, como em tantos outros campos de investigação. Parece-me que em nenhum outro momento isso é mais claro do que nas Leis, que, a propósito de suas opiniões sobre alma e corpo, é praticamente um compêndio das concepções que elaborou por toda uma vida intelectual. Digo "praticamente", porque a tripartição da alma é uma idéia que agora existe somente como uma série de disiecta membra da idéia original; a antiga bipartição em razão e impulso, que tão bem serviu a Platão até a elaboração da República, parece ter voltado como seu modelo favorito de estrutura psíquica. Fora isso e, claro, a notável concepção de alma como motor automovente elaborada primeiramente no Fedro, o retrato da alma é muito mais aquele presente em diálogos anteriores, onde, como afirmei noutro lugar:

A vida é um processo de purificação (do corpo) e assimilação ao divino (716c-e); a alma é o verdadeiro eu e goza de imortalidade pessoal (959b3-4); os justos são recompensados numa vida futura, e há sanções reservadas aos viciosos; parte-se de uma distinção substancial fundamental entre alma e corpo, e os "prazeres" são, uma vez mais, tratados com desconfiança $(672 \mathrm{~d} 8-9$, 727c1 e segs. etc.); os elementos da alma são novamente descritos indiscrimina- 
damente como "bons" e "maus"... (904b2-3), a despeito da reavaliação cuidadosa dessas idéias na República 9 e no Filebo.

Mais uma concepção de alma nas Leis é digna de menção, a idéia de que, enquanto uma força vital, ela consiste em alguma forma de Stoff que permeia e dirige o universo físico como um todo e todos os seres vivos nele. Enquanto tal, é neutra ética e intelectualmente, e ganha coloração ética e intelectual somente quando opera "com a sabedoria como sua auxiliar", ou quando "se associa à insensatez"(897b1,3). Em vários sentidos, a idéia é uma versão levemente refinada da concepção um tanto ectoplásmica de alma que surgiu inicialmente no Fédão e se efetua nas Leis como uma das várias concepções rivais que se apresentam a nosso exame comparativo, quase ao modo como o fizeram no Fédão.

Essa clara disposição a retornar a suas concepções, contradições e tudo mais da juventude, ignorando em muito o modo de elucidação e correção cuidadosas que caracterizou diálogos como a República, o Timeu e o Fedro, foi, para alguns leitores de Platão, motivo de escândalo, a ponto de um autor, achando o diálogo todo uma paródia da filosofia de Platão, ter defendido que realmente não é obra sua (Mueller, 1951, p. 190). Mas a conclusão é extravagante. Longe de prejudicar Platão, a evidente má vontade que mostra para reduzir a algum tipo de ordem artificial uma série de conceitos de alma que, provavelmente, são intrinsecamente inconciliáveis, talvez se mostre melhor como signo de seu vigor filosófico. Sem dúvida, o fato de ter feito claros progressos sobre vários temas em alguns diálogos médios e tardios sugere que se tornou cada vez mais consciente, se não o estava desde o início, de alguns problemas presentes em suas formulações anteriores da natureza da alma e da natureza da relação alma-corpo. Que, na velhice, tenha sentido necessidade de questionar se o que naqueles diálogos parecia progresso realmente o era, isso, é claro, pode ser um sinal de crescente decrepitude senil de sua parte. Mas isso parece poder ser atribuído também (ou com mais razão) a uma sua resolução de, em caso de dúvida, deixar abertas suas opções; resolução de um homem que, em qualquer tema, escolheu afinal expressar-se na forma aberta do diálogo, não na forma dogmática do tratado.

Creio que em nenhum outro lugar isso é mais evidente do que nas Leis 898e8-899a4. Após despender uma vida discutindo vários aspectos da relação alma-corpo, ele retorna ao tema pela última vez, talvez pouco antes de sua morte. Tomando o sol como exemplo de objeto animado, menciona três possíveis modos de sua alma controlar seu corpo: de dentro, como faz "nossa própria alma"; de fora; ou "controlando-o" de algum outro misterioso modo, "despojada 
do corpo e de posse de outros poderes maravilhosos". Ao fim, ele está lutando com o problema que jaz no coração de todo dualismo psicofísico, o de relacionar uma substância física a uma imaterial, e termina por admitir abertamente sua perplexidade. Eis um esplêndido tributo a sua honestidade intelectual.

Tradução integral

ROBERTO BOLZANI FILHO** Faculdade de Filosofia, Letras e Ciências Humanas da Universidade de São Paulo

\section{Notas}

* Professor Doutor de Filosofia da University of Toronto e Presidente da International Association for Greek Philosophy (desde 1993) e da International Plato Society (desde 1995).

** Professor de Filosofia da Faculdade de Filosofia, Letras e Ciências Humanas da USP.

1 Para os propósitos desta discussão, assumirei o seguinte: a) que as obras de Platão se dividem em três grupos principais, distinguíveis como "socrático", "médio" e "tardio"; b) que as concepções de alma encontradas no grupo socrático são mais ou menos as do Sócrates histórico, as encontradas nos dois últimos grupos, mais ou menos as de Platão. Optei também, todo o tempo, pela tradução mais antiga de psyche por "alma" [soul], de preferência a "mente" [mind], principalmente porque essa tradução me parece apreender melhor o sentido de psyche como a "pessoa" ou "eu genuíno", que parece ter sido o que Platão se empenhara por afirmar.

2 Para um estudo cuidadoso da metempsicose no pensamento grego antigo e suas origens não gregas, ver: Burkert, 1972, p. 120-65.

3 Alc. 1 130c5-6 e, implicitamente, Protag. 313a-b. A esse respeito, ver: Robinson, 1970, p. 12. A noção é também afirmada claramente em Fédão 115c e Rep. 469d6-9. Alternativamente, Platão pode ter sustentado que o eu consiste na alma utilizando o corpo como um instrumento (Alc. 1 130a1-3); o estatuto duvidoso do diálogo em questão, no entanto, torna difícil estarmos seguros disso.

4 Para discussão dos detalhes, ver: Robinson, 1970, p. 9.

5 Em Tim. 36d-e, Platão fala do corpo do mundo como sendo modelado pelo Demiurgo no interior de sua alma, não - como se poderia esperar - vice-versa.

6 Expresso-me tentativamente, porque os mitos devem ser encontrados no decurso de todos os diálogos, e é muito difícil saber se foram uma característica das conversações do Sócrates histórico ou não. 
7 A noção do corpo como um túmulo (temporal) para a alma implica ao menos que a longevidade da alma é maior do que a do corpo; em Menon, 86a8-b2 Sócrates parece satisfeito com o fato de o suposto pré-conhecimento de verdades geométricas do escravo ser de fato evidência em favor da imortalidade da alma.

8 Em Plato's Psychology, argumentei pela opinião de que ele se inclinou à concepção órfica; para a defesa da posição contrária, ver: Shiner, 1972, p. 23-30.

9 Em 90e6-7, Platão escreve de um modo que sugere que a diferenciação em homem e mulher fora instituída pelo Demiurgo já no início, e mesmo se poderia dizer de uma passagem anterior em 41e-42a. Mas isso parece ser um deslize de sua parte, que vai inteiramente de encontro ao curso geral de seu argumento, no qual todos recebem do Demiurgo, no início, uma chance igual (41e4). Ver também a evidência de 91d7 (andron), onde Platão parece continuar uma discussão das várias punições distribuídas a homens primitivos, e 42b3-c1, onde, novamente, parece tratar-se de homens somente.

10 Literalmente, "injusto". O sentido, contudo, como na República, parece ser muito amplo, cobrindo todo o âmbito das ações não virtuosas.

11 Cf. 42a2. Mas a referência poderia ser à bondade moral supostamente maior dos homens; o adjetivo comparativo kreitton, aqui como em outras passagens, é radicalmente ambíguo.

12 Para evidência adicional da posição de Platão sobre o tema, ver (lamentavelmente) Leis, 781a-d.

13 Mas não é mera repetição. O fato de o cavalo bom e o condutor serem praticamente indistinguíveis em termos de seus desejos (racionais) e ações sugere que Platão está à beira de retornar à sua crença anterior na bipartição básica da alma em razão e impulso.

\section{RefERÊnCias Bibliográficas}

BURKERT, W. Lore and Science in Ancient Pythagoreanism. Translated by Edwin L. Minar Jr. Harvard: 1972.

BURNET, J. The Socratic Doctrine of the Soul. Proceedings of the British Academy. n. 7, p. 235s, 1916.

DODDS, E. R. The Greeks and the Irrational. Berkeley: 1951.

MUELLER, G. Studien zu den Platonischen Nomoi. Munique: 1951.

ROBINSON, T. M. Plato's Psychology. Toronto: 1970. . Introdução. In: . Plato's Psychology. 2 ed. Toronto: no prelo.

SHINER, R. A. Soul in Rep. X, 611. Apeiron. n. 6, p. 23-30, 1972. 
ROBINSON, Thomas M. The defining features of mind-body in the writings of Plato.

ABSTRACT: The works of Plato contain the first fully articulated account of the relationship between soul and body in Western literature. On the one hand, Socrates thinks, according to the Orphics and Pythagoreans, soul is the ground of our real self, and the body, the "tomb" of the soul. On the other hand, he talks as though both body and soul are the possession of a third entity wich - whatever it is - is the genuine self. Having spent a life-time discussing, in many dialogues (Phaedo, Gorgias, Republic, Timaeus, Phaedrus), various aspects of the soul-body relationship, Plato returns to the topic for one last time, in a passage at Laws. To the end he is wrestling with the problem that lies at the heart of all psycho-physical dualism, the problem of relating a physical substance to an immaterial one, and to the end he openly admits his bafflement.

KEYWORDS: soul-body relationship; psycho-physical dualism; Orphism; Pythagoreanism; Plato. 